\title{
Studies on the composition of food
}

\section{4.* Comparison of the nutrient content of retail white bread made conventionally and by the Chorleywood Bread Process}

\author{
By R. A. KNIGHT \\ Flour Milling and Baking Research Association, Chorleywood, Herts. \\ AND A. A. CHRISTIE \\ Department of Trade and Industry, Laboratory of the Government \\ Chemist, London $S E_{\text {I }}$ \\ AND C. R. ORTON AND JEAN ROBERTSON \\ Ministry of Agriculture, Fisheries and Food, London SW $\mathbf{I}$ \\ (Received 5 July 1972-Accepted I9 February 1973)
}

\begin{abstract}
I. Loaves of conventional white bread and of bread made by the Chorleywood Bread Process (CBP) were bought from bakers' shops in Britain over a ro-month period and were bulked to give samples representative of each type of bread produced for consumption in the country as a whole. These were analysed for moisture, protein and amino acids, fats and fatty acids, carbohydrate (by difference), sodium, potassium, iron, thiamin, riboflavin, total and available nicotinic acid, vitamin $B_{6}$, and free folic acid.

2. There were no great differences between the nutrient contents of the two types of bread. The mean moisture contents differed by only $5 \mathrm{~g} / \mathrm{kg}$ but a variation was found between some selected nutrients in paired loaves of the same type. CBP bread could not be distinguished from conventional bread in its content of fat, ash, calcium, sodium, potassium, thiamin, total and available nicotinic acid and vitamin $\mathbf{B}_{6}$. The content of riboflavin was slightly higher, and of protein and carbohydrate slightly lower in CBP bread than in conventional bread. Differences in fatty acid composition of the two types of bread and in their content of total sulphur-containing amino acids were slight.
\end{abstract}

The Chorleywood Bread Process (CBP), which was introduced to the baking industry in $\mathrm{r} 96 \mathrm{I}$, has gained such widespread acceptance that between 75 and $80 \%$ of the bread produced in Great Britain is now made in this way. In an earlier paper in this series the essential features of the CBP were described and the nutrient contents of conventional and CBP bread were compared (Chamberlain, Collins, Elton, Hollingsworth, Lisle \& Payne, 1966). The breads concerned were made in a commercial bakery from two white flours, one 'weak' and one 'strong'. Both the flours and the breads were analysed for moisture, protein, ash, fat, carbohydrate (by difference), thiamin, nicotinic acid and ascorbic acid. Breads made in a pilot-scale bakery from two other flours were used to determine net protein utilization values in feeding trials with rats. It was found that, whereas the CBP bread contained slightly more moisture and thiamin and slightly less carbohydrate than the bread made conventionally from the same flour, the two types of bread could not be distinguished in terms of protein, fat, ash and nicotinic acid contents, and in protein quality as indicated by its net

* Paper no. 3:Br. F. Nutr. (1968), 22, 2 I. 
Table $\mathrm{I}$. Contribution of white bread to the nutrient content of the average British household diet*

\begin{tabular}{lcc}
\multicolumn{1}{c}{ Nutrient } & g/g total intake & Per head per d \\
Energy (kJ/kJ total intake) & 0.128 & $1377 \mathrm{~kJ}$ \\
Protein & 0.148 & $1 \mathrm{I} .0 \mathrm{~g}$ \\
Fat & $0.01 \mathrm{I}$ & $\mathrm{I} 4 \mathrm{~g}$ \\
Carbohydrate & 0.228 & $72 \mathrm{~g}$ \\
Calcium & 0.122 & $128 \mathrm{mg}$ \\
Iron & 0.134 & $\mathrm{I} .8 \mathrm{mg}$ \\
Thiamin & 0.192 & $0.22 \mathrm{mg}$ \\
Riboflavin & 0.023 & $0.04 \mathrm{mg}$ \\
Total nicotinic acid & $0.1 \mathrm{Ig}$ & $1.9 \mathrm{mg}$ \\
Nicotinic acid equivalents & 0.098 & $2.9 \mathrm{mg}$
\end{tabular}

* Ministry of Agriculture, Fisheries and Food: National Food Survey Committee (1971).

protein utilization value. No ascorbic or dehydroascorbic acid was detected in any of the bread.

These results suggested that the difference in nutrient content of the two types of bread when made from the same flour was small and of little or no significance in relation to the average British diet. However, since white bread makes such an important contribution to the nutrient content of the average diet (Table I), and since special flours suitable for use with the CBP have been developed and are now widely used, it seemed desirable to carry out a more broadly based survey. Accordingly, arrangements were made to obtain samples of both CBP and conventionally made loaves from retail outlets in different areas of Great Britain and to carry out a comprehensive analysis of these samples. This paper presents the results obtained in the course of this survey.

\section{EXPERIMENTAL}

\section{Scope of the survey}

Large $794 \mathrm{~g} \mathrm{(28} \mathrm{oz)} \mathrm{sliced,} \mathrm{wrapped} \mathrm{loaves} \mathrm{(which} \mathrm{are} \mathrm{the} \mathrm{predominant} \mathrm{type)} \mathrm{were}$ purchased from retail shops in selected areas in England, Scotland and Wales by Liaison Officers of the Flour Milling and Baking Research Association over a period of about io months (July I 966 to April 1967). All the loaves were produced in largescale 'plant' bakeries and the type of bread concerned (CBP or conventional) was identified by previous consultation with the bakery supplying the bread to the shop. In an attempt to obtain representative samples, duplicate loaves of each type of bread were purchased on at least five separate occasions in each area. A total of thirty-five pairs of CBP loaves and thirty-two pairs of conventionally made loaves were sampled in this way.

\section{Sampling procedure}

The loaves were left in their original wrappers, overwrapped in two layers of polyethylene film and posted in cardboard boxes to the Research Station at Chorleywood on the day of purchase.

Six pairs of loaves (three pairs of each type of bread) were examined individually 
for a selected number of nutrients to assess the variation between loaves; the remaining duplicate loaves were mixed on an equal-weight basis to form single samples, which were examined for the same nutrients (Table 3). The samples of each type of bread were then amalgamated to form a single bulk, the samples being weighted according to their original moisture content. The two bulked samples, representing CBP bread and conventional bread respectively, were analysed in quadruplicate to obtain values for a range of nutrients which might be considered as representative of the nutrient content of the two types of bread as produced for consumption in the country as a whole.

\section{Analytical methods}

Moisture in whole loaf. Each loaf was weighed, air-dried under ambient conditions on racks at temperatures ranging from 20 to $25^{\circ}$, reweighed and ground. The moisture content of the air-dried bread was determined by drying a $4^{-6} \mathrm{~g}$ sample at $103^{\circ}$ for $5 \mathrm{~h}$. Representative samples of the ground material were freeze-dried to reduce the moisture content further and stored at $-15^{\circ}$ until required for nutrient analysis.

Protein. Nitrogen was determined by the Kjeldahl method of the Ministry of Agriculture, Fisheries and Food (I968) except that the distillate was collected in $0.65 \mathrm{M}$-boric acid. Protein is expressed as $\mathrm{N} \times 5.7$.

Amino acids. The protein in finely powdered bread (100 $\mathrm{mg}$ ) was hydrolysed with $5 \mathrm{ml} 6 \mathrm{M}$-hydrochloric acid in an evacuated sealed tube for $24 \mathrm{~h}$ at $100^{\circ}$. The liberated amino acids were then separated on a Technicon AutoAnalyzer (Model NC I ; Technicon Instruments Co. Ltd, Basingstoke, Hants.) by means of gradient elution from an ion-exchange column and determined by colorimetric reaction with ninhydrin. Cystine and methionine were determined on pre-oxidized samples by the method of Moore (1963); tryptophan was determined after alkaline hydrolysis by the method of Miller ( 1967 ). Under the hydrolytic conditions used, recoveries of glutamic acid, isoleucine, leucine, serine and valine were low and were corrected by factors obtained in a study of the respective yields of the acids with increasing periods of hydrolysis.

Fat. The acid hydrolysis method described by Kent-Jones \& Amos (I 967) was used. Fatty acids were determined, as their methyl esters, by gas-liquid chromatography using a dual-flame ionization detector, isothermal chromatograph with heated injection block. The methyl esters were obtained by transesterification, using methanol and hydrochloric acid, of the fat extracted by methanol and chloroform.

Carbohydrate. Total carbohydrate was estimated by difference.

$A s h$. Samples of 5 or $\mathrm{rog}$ were ashed at $55^{\circ}$. Sodium and potassium were determined on the ash obtained by heating a $10 \mathrm{~g}$ sample at $55^{\circ}$. The ash was treated with $6 \mathrm{M}$-hydrochloric acid and the insoluble residue was evaporated with a mixture of $6 \mathrm{M}$-hydrochloric acid and $6 \mathrm{M}$-nitric acids. After removal of the nitric acid the extracts were combined and sodium and potassium were measured on an EEL single-photocell flame-photometer (Evans Electroselenium Ltd, Halstead, Essex) fitted with optical filters. Iron content was determined by the method of the Association of Official Analytical Chemists ( 1970 ) on the ash obtained by heating a ro g sample at $55^{\circ}$.

Vitamins. Thiamin was determined by the method recommended by the (UK) Sub-Committee on Vitamin Estimations (Society of Public Analysts and other 
Analytical Chemists: Analytical Methods Committee, I95I), except that sodium hydroxide and potassium ferricyanide reagents were added separately. The stage involving isolation of the thiamin on a zeolite column was omitted. Riboflavin was determined by the microbiological assay of Barton-Wright (I962), available nicotinic acid (nicotinic acid and nicotinamide) by the method of Clegg ( 1963$)$, total nicotinic acid (nicotinic acid, nicotinamide and bound nicotinic acid) by the microbiological assay of Barton-Wright (196I), and vitamin $B_{6}$ by the microbiological assay of Storvick, Benson, Edwards \& Woodring (I960) with Saccharomyces carlshergensis as test organism. For determination of free folic acid, samples were homogenized with a 0.2 M-phosphate buffer solution, $\mathrm{pH} 6 \cdot \mathrm{I}$, containing $\mathrm{I} \mathrm{g}$ ascorbic acid/1 according to the method of Eigen \& Shockman (1963) and the free folic acid content was measured by microbiological assay with Lactobacillus case $i$ as the test organism.

\section{RESULTS AND DISCUSSION}

The mean analytical results for the breads are given in Tables 2-5.

\section{Individual loaves}

For all constituents except sodium and potassium, the variation between loaves of the same types was statistically significant $\left(P<0^{\circ} 05\right)$, i.e. was greater than would have been expected if the observed variation between individual loaves had been entirely due to the methods of sampling and analysis. Estimates of the variation due to sampling and analysis were obtained from the results of the quadruplicate analyses of the bulked samples. The only nutrient showing a significant difference between types of loaves was iron.

Moisture. The difference between the mean moisture contents of the CPB and conventional loaves was small $(5 \mathrm{~g} / \mathrm{kg})$. The significance of this difference is difficult to assess because it was confounded with significant $(P<0.01)$ differences in the results obtained on different occasions of sampling. Since there was no control over the formulations used by the different bakeries manufacturing the bread sampled and it was not possible to obtain 'matching' pairs of CBP and conventional loaves throughout the ro-month period of the survey, it is difficult to draw valid conclusions from the statistical analysis of the results. CBP bread doughs normally contain more water than bulk-fermented doughs, about $4.5 \mathrm{~kg}$ more water being added per $127 \mathrm{~kg}(280 \mathrm{lb})$ sack of flour, equivalent to about $22 \mathrm{~g} / \mathrm{kg}$ of total dough weight. The absence of several hours of bulk fermentation of the dough after mixing means that, in a short-time process such as CBP, flour solids that would in a conventional process be lost are retained in the final product. The retained solids largely compensate for the extra water added to CBP doughs.

It may be calculated from information about fermentation that CBP bread should contain slightly more moisture than bread made by a bulk-fermentation process. Thus the observed difference of $5 \mathrm{~g} / \mathrm{kg}$ between the mean moisture contents of the two types of bread sampled probably represents a real difference. Chamberlain $e t$ al. (I966) obtained differences of $7 \mathrm{~g} / \mathrm{kg}$ and $12 \mathrm{~g} / \mathrm{kg}$ in moisture content of bread made commercially with weak and strong flours respectively. 
Table 2. Comparison of the nutrient content of bread made by the Chorleywood Bread Process (CBP) and conventional bread

(Mean values of quadruplicate estimates from bulked loaves)

\begin{tabular}{|c|c|c|c|c|}
\hline \multirow[b]{2}{*}{ Nutrients $/ \mathrm{kg}$} & \multicolumn{2}{|c|}{ Dry wt } & \multicolumn{2}{|c|}{ As eaten } \\
\hline & CBP bread & $\begin{array}{l}\text { Conventional } \\
\text { bread }\end{array}$ & CPB bread & $\begin{array}{l}\text { Conventional } \\
\text { bread }\end{array}$ \\
\hline Moisture (g) & - & - & 390 & 385 \\
\hline Protein $(\mathrm{N} \times 5.7)(\mathrm{g})$ & 132 & 136 & 80 & 84 \\
\hline Fat $(g)$ & 27 & 28 & 17 & 17 \\
\hline $\begin{array}{l}\text { Available carbohydrate (as } \\
\text { monosaccharide)* (g) }\end{array}$ & 890 & 887 & 543 & 546 \\
\hline Energy value* $(\mathrm{kJ})$ & & & то 680 & 10790 \\
\hline Ash (g) & 32 & 31 & 19 & 19 \\
\hline Calcium (mg) & I 700 & I 600 & I 000 & 1000 \\
\hline Sodium (mg) & 8900 & 8700 & 5400 & 5400 \\
\hline Potassium (mg) & 1700 & 1600 & I 000 & 1000 \\
\hline Iron (mg) & 28 & 29 & 17 & I8 \\
\hline Thiamin (mg) & 3 & 3 & $\mathrm{I} \cdot 8$ & I -8 \\
\hline Riboflavin (mg) & 0.4 & 0.3 & 0.3 & 0.2 \\
\hline Available nicotinic acid (mg) & 13.5 & 13.4 & $8 \cdot 2$ & $8 \cdot 3$ \\
\hline Total nicotinic acid (mg) & 23.4 & 23 & 14.3 & I4 \\
\hline Nicotinic acid equivalent $\uparrow$ (mg) & & & $26 \cdot 2$ & 25 \\
\hline Vitamin $\mathbf{B}_{0}(\mu \mathrm{g})$ & 650 & $6_{5} \circ$ & 400 & 400 \\
\hline Folic acid, free (Lactobacillus casei) $(\mu \mathrm{g})$ & IOO & 100 & 60 & 60 \\
\hline
\end{tabular}

The moisture contents are taken from the analyses of individual loaves. Only the differences shown for protein and riboflavin were statistically significant $(P<0.05)$.

* Calculated values : factors of 17,37 and $16 \mathrm{~kJ} / \mathrm{g}$ were used for protein, fat and carbohydrate (as monosaccharide) respectively.

+ Calculated value: I $\mathrm{mg}$ nicotinic acid equivalent is defined as I $\mathrm{mg}$ available nicotinic acid or $60 \mathrm{mg}$ tryptophan.

\section{Table 3. Nutrient content of individual loaves of bread made by the Chorleywood Bread Process (CBP) and conventional bread as bought}

(Mean values of all pairs of loaves, including the six pairs examined individually)

\begin{tabular}{lrrrr} 
& \multicolumn{3}{c}{ Conventional bread } \\
Nutrient/kg & $\overbrace{\text { Mean }}^{\text {CBP bread }}$ & $\overbrace{\text { Mean }}^{\text {SD }}$ & SD \\
Moisture (g) & 391 & Io & 385 & I0 \\
Ash (g) & 19 & 1 & 19 & I \\
Calcium (mg) & 1000 & 180 & I 100 & I 40 \\
Sodium (mg) & 5200 & 290 & 5200 & 340 \\
Potassium (mg) & 1000 & 80 & 1000 & 70 \\
Iron (mg) & 16 & 2 & 18 & 2.5
\end{tabular}

\section{Bulked samples: nutrients}

There were no great differences between the nutrient contents of the two types of bread (Tables 2-4).

Statistical analysis of the results in Table 2 confirmed that the differences between the values for fat, ash, calcium, sodium, potassium, iron, thiamin, total and available nicotinic acid and vitamin $\mathrm{B}_{6}$ were not significant. 
Table 4. Fatty-acid content $(\mathrm{g} / \mathrm{kg})$ of breads made conventionally and by the Chorleywood Bread Process (CBP)

(Mean values of duplicate estimates from bulked samples of bread as bought)

$\begin{array}{lcccc}\text { Fatty acid } & \mathrm{I} 6: 0 & \mathrm{I} 8: 0 & \mathrm{I} 8: \mathrm{I} & \mathrm{r} 8: 2 \\ \text { CBP bread } & \mathrm{I} \cdot 8 & 0.7 & \mathrm{I} \cdot 7 & \mathbf{2} \cdot 2 \\ \text { Conventional bread } & \mathrm{I} \cdot 8 & 0.6 & \mathrm{I} \cdot 8 & 2 \cdot \mathrm{I}\end{array}$

Other acids determined (12:0, 14:0 and $18: 3$ ) were of the order of $0.2 \mathrm{~g}$ per $\mathrm{kg}$ or less for both types of bread.

Table 5. Amino acid content of breads made by the Chorleywood Bread Process $(C B P)$ and conventional bread

(Mean values of quadruplicate determinations on loaves as bought)

\begin{tabular}{|c|c|c|c|c|}
\hline \multirow[b]{2}{*}{ Amino acid } & \multicolumn{2}{|c|}{ CBP bread } & \multicolumn{2}{|c|}{ Conventional bread } \\
\hline & $\begin{array}{c}\text { g amino } \\
\text { acid } / \mathrm{kg} \text { bread }\end{array}$ & $\begin{array}{l}\operatorname{mg} \text { amino } \\
\mathrm{acid} / \mathrm{g} N\end{array}$ & $\begin{array}{c}\text { g amino } \\
\text { acid/kg bread }\end{array}$ & $\begin{array}{c}\operatorname{mg} \text { amino } \\
\text { acid/g N }\end{array}$ \\
\hline Alanine & 26 & 190 & 26 & 180 \\
\hline Arginine & $3 I$ & 220 & $3 I$ & 210 \\
\hline Aspartic acid & 38 & 270 & 39 & 270 \\
\hline Cystine & 24 & 170 & 24 & 160 \\
\hline Glutamic acid & 290 & 2060 & 308 & 2090 \\
\hline Glycine & 28 & 200 & 29 & 200 \\
\hline Histidine & 18 & 130 & 19 & I 30 \\
\hline Isoleucine & 34 & 240 & 35 & 240 \\
\hline Leucine & 62 & 440 & 64 & 440 \\
\hline Lysine & 17 & 120 & I8 & I 20 \\
\hline Methionine & 19 & 140 & I9 & I 30 \\
\hline Phenylalanine & 42 & 300 & 42 & 290 \\
\hline Proline & I IO & 790 & I 4 & 780 \\
\hline Serine & 49 & 350 & 52 & 350 \\
\hline Threonine & 24 & 170 & 25 & 170 \\
\hline Tryptophan & II & 80 & I I & 70 \\
\hline Tyrosine & 22 & 160 & 23 & 160 \\
\hline Valine & $3^{8}$ & 270 & 40 & 270 \\
\hline
\end{tabular}

Differences in the fatty acid composition of the two types of bread (Table 4), including differences in the contents of octadecadienoic ( $18: 2)$ and octadecatrienoic acid (18:3), were slight. The fat recovered as fatty acids accounted for approximately half of the total fat obtained by the acid hydrolysis method.

The slightly higher content of thiamin found in the CBP bread by Chamberlain et al. (1966) was not apparent in these samples.

In the earlier experiment breads of both types had a similar protein content when made from the same flour. The differences between the protein contents of the two types of bread found in the present study are likely to be the result of the rather lower protein content of the flours that are used in the commercial production of CBP bread.

The amino acid content of both types of bread after hydrolysis of the protein (Table 5) is in broad agreement with values given for white bread in the literature. 
The amino acids which are most commonly limiting in the average British diet are the sulphur-containing amino acids (Greaves \& Tan, 1 966); the mean values for the bulked samples do not suggest that these are reduced by the CBP.

The relative proportions of natural sugars, starch, maltose and dextrins in bread vary with the amylase activity and damaged starch content of the flour, the fermentation time, the temperature and yeast content of the dough, and the baking conditions. In the CBP, bulk fermentation is eliminated and both the yeast content and temperature of the dough are increased (Chamberlain et al. 1966). It is to be expected therefore that the sugar content of $\mathrm{CBP}$ bread may differ from that of bread made conventionally by a bulk-fermentation process.

Total carbohydrate was estimated by difference. The figures obtained were converted into monosaccharide equivalents by calculation using predicted values for the starch, reducing sugar, non-reducing sugar and water-soluble dextrin contents of the two types of bread and applying appropriate conversion factors ( $I$. II for starch, $\mathrm{I} \cdot 05$ for maltose, $\mathrm{I} \cdot 09$ for dextrins). The predicted values concerned were obtained from the results of an earlier investigation carried out by one of us (R.A.K.) in which the sugar and dextrin contents of the crumb of $794 \mathrm{~g} \mathrm{(28} \mathrm{oz)} \mathrm{loaves} \mathrm{made} \mathrm{convention-}$ ally and by the CBP were determined. On this basis the available carbohydrate content (as monosaccharides) of the conventional bread was slightly higher than that of CBP bread.

The levels of 'free' or non-conjugate folic acid were only about one-third of those found by Hurdle, Barton \& Searles (1968) in white bread. Comparison of the techniques used by Hurdle et al. and by the Laboratory of the Government Chemist has shown that this discrepancy is unlikely to be the result of methodological differences.

We thank all the members of staff of the Flour Milling and Baking Research Association and the Laboratory of the Government Chemist who participated in this study.

\section{REFEREN CES}

Association of Official Analytical Chemists (1970). Official Methods of Analysis of the Association of Official Analytical Chemists i th ed., p. 212. Washington, DC: Association of Official Analytical Chemists.

Barton-Wright, E. C. (1961). Lab. Pract. 1o, 633 .

Barton-Wright, E. C. (1962). Lab. Pract. 11, 28.

Chamberlain, N., Collins, T. H., Elton, G. A. H., Hollingsworth, D. F., Lisle, D. B. \& Payne, P. R. (1966). Br. F. Nutr. 20, 747.

Clegg, K. M. (1963). Br. F. Nutr. 17, 325 .

Eigen, E. \& Shockman, G. D. (1963). In Analytical Micrabiology p. 45I [F. Kavanagh, editor]. New York and London: Academic Press.

Greaves, J. P. \& Tan, J. (I966). Nutrition, Lond, 20, I I2.

Hurdle, A. D. F., Barton, D. \& Searles, I. (I968). Am. F. clin. Nutr. 21, r 202.

Kent-Jones, D. W. \& Amos, A. J. (1967). Modern Cereal Chemistry 6th ed., p. 566. London: Food Trade Press Ltd.

Miller, E. L. (1967). F. Sci. Fd Agric. 18, 38 I.

Ministry of Agriculture, Fisheries and Food: National Food Survey Committee (1971). Domestic Food Consumption and Expenditure: 1969. London: HM Stationery Office. 
Ministry of Agriculture, Fisheries and Food (1968). Fertilisers and Feeding Stuffs Regulations. Stat. Instrum. 1968 no. 218.

Moore, S. (1963). F. biol. Chem. 238, 235.

Society of Public Analysts and Other Analytical Chemists: Analytical Methods Committee (195I). Analyst, Lond. 76, 127.

Storvick, C. A., Benson, E. M., Edwards, M. A. \& Woodring, K. J. (1960). In Methods of Biochemical Analysis Vol. 8, p. 229 [D. Glick, editor]. New York: Interscience. 